\title{
The Growth Hormone Level of Bali Cattle's Post Treatment with Ethinil Esthradiol and Progesteron Hormones in Combination with Mineral
}

\author{
Aletha Yuliana Mandala ${ }^{1 *}$, Ni Ketut Suwiti², I Wayan Suardana ${ }^{2}$ \\ ${ }^{1}$ Student of Veterinary Postgraduate Udayana University \\ ${ }^{2}$ Biotechnology Laboratory of Veterinary Center Denpasar, Bali \\ Denpasar-Bali \\ *Corresponding Author: mandalaaletha@gmail.com
}

\begin{abstract}
This study aims to find out the growth hormone level of bali cattle's post giving of ethinyl estradiol and progesterone hormones combined with mineral. The total sample of 64 bali cattle is divided into 4: Group I (Control) is not given hormone ethinyl estradiol, progesterone and mineral. Group II is given the hormone ethinyl estradiol and progesterone, without mineral. Group III was not given ethinyl estradiol and progesterone hormones, with mineral administration. Group IV is given hormone ethinyl estradiol, progesterone and mineral. At the end of the study, measurements were performed to determine the growth hormone level using ELISA method. The data of the research were analyzed by the analysis of variance. The result showed that male cattle growth hormone $(268.281 \pm 73.13 \mathrm{pg} / \mathrm{ml})$ was higher than females $(236.250 \pm 13.79 \mathrm{pg} / \mathrm{ml})$. The growth hormone level of young cattle was higher $(264.94 \pm 74.42 \mathrm{pg} / \mathrm{ml})$ than adult $(239.59 \pm 14.05 \mathrm{pg} / \mathrm{ml})$. Level of growth hormone of bali cattle with highest minerals $(266.97 \pm 74.15 \mathrm{pg} / \mathrm{ml})$ compared without minerals $(237.56 \pm 11.05 \mathrm{pg} / \mathrm{ml})$. The growth hormone level of bali cattle with higher levels of ethinyl estradiol and progesterone hormone $(263.31 \pm 74.81 \mathrm{pg} / \mathrm{ml})$ compared with no ethinyl estradiol and progesterone hormone $(241.22 \pm 18.8 \mathrm{pg} / \mathrm{ml})$. The results are age and sex effect on growth hormone level with hormone ethinyl estradiol and progesterone combined with mineral. Giving ethinyl estradiol and progesterone hormones combined with significant mineral $(\mathrm{P}<0.05)$ may increase the growth hormone level of young male bali cattle.
\end{abstract}

\section{Keywords: Growth hormone, bali cattle, ethinyl estradiol and progesterone hormone, minerals, ELISA.}

\section{INTRODUCTION}

Bali cattle is one of the local cattle in Indonesia besides the cattle of Aceh, coastal, and Madura. Bali cattle have a high fertility rate $(80 \%-82 \%)$, good adaptability to marginal environments. They also are easily farmed almost in every region in Indonesia and even abroad for instance Malaysia, Philippines and Australia [1].

Its activity in growth depends on several factors that involve food supplies, geneticpotential, and environment. Fodder also greatly affects the growth hormone level. Indirectly, growth hormone works through the hormone insulin-like growth factor 1 (IGF-1) which is produced by various tissues in response to growth hormone [2]. One important factor in regulating IGF-1 is fodder. Minerals and proteins will increase the IGF-1 levels in cattle's body and otherwise mineral and protein deficiencies can lower IGF-1 levels, resulting in a decrease in growth hormone secretion that ends in a decrease in growth hormone level [3]. The use of hormones also 
affects the growth hormone level. There are several hormones play an important role in growth phase, such as somatotropin, thyroxine, androgen, a combination of estrogen and progesterone, and glucortikoid [4][5]. Ethinyl estradiol and progesterone can stimulate the growth hormone secretion of the pituitary gland and cause increased levels of insulin in the blood so as to facilitate the metabolism of carbohydrates and amino acids, the need for energy is fulfilled, and amino acids for muscle formation proteins due to increased concentrations of somatotropin and IGF-1 so that blood growth hormone levels increase [6][7][8].

Giving ethinyl estradiol and progesterone combined with minerals can influence the growth hormone level that can be measured by using ELISA method [9]. This study aims to determine the growth hormone level of bali cattle both males and females in young and post adulthood postadduction of ethinyl estradiol and progesterone hormones combined with mineral administration.

\section{RESEARCH METHOD}

\section{Research Materials}

This study used a Bovine Growth Hormone ELISA kit consisting of microplate 96 well, standard, A (Biotin conjugated antibody specific) and B (Avidin conjugated Horse Radical Peroxidase), substrate (Tetrametyl benzidine), wash buffer, paper plate, standard diluent, diluent assays $\mathrm{A}$ and $\mathrm{B}$, stop solution, PBS, and distilled water.

The target population in this study was 64 bali cattle that were kept intensive at Mupu Amerta farm in Bangli Regency, Bali Province.The 64 samples were divided into 16 young cattle, 16 adult cattle, 16 young cattle and 16 adult female cattle, grouped into 4: Group I (Control Group) which not given ethinyl estradiol, progesterone and mineral hormones. Group II was given ethinyl estradiol and progesterone hormones, without mineral supplements. Group III was not given ethinyl estradiol and progesterone hormones, with mineral supplements. Group IV was given ethinyl estradiol, progesterone and mineral hormones.

Serum samples were obtained from blood collection using a venoject needle, through a jugular vein that take around 10 $\mathrm{ml}$ of blood. Serum is placed at room temperature for 10-20 minutes, then it centrifiuge at a speed of 2000-3000 rpm for 20 minutes to avoid sedimentation.

\section{Measurement of Growth Hormone Level}

The ELISA test procedure used in this study refers to Glory Science [10] methods. This test is performed based on the standard operating procedure Bovine Growth Hormone (GH) ELISA Kit.

The research procedure begins with standard dilution done by mixing the standard with the standard dilution.Firstly, prepared 5 efendorf tubes, then taken $50 \mu \mathrm{l}$ standard dilution to fill in each efendorf tube, then taken as $100 \mu \mathrm{l}$ standard (5400pg / $\mathrm{ml}$ ) and inserted into the first tube.A total of $100 \mu \mathrm{l}$ of the solution (standard mixture of dilution and standard) is taken from the first tube and put into the second tube.A total of $50 \mu \mathrm{l}$ of solution from the second tube is taken and inserted into the third tube. In this third stage this process repeated until the fifth tube so that the standard concentration is worth $300 \mathrm{pg} / \mathrm{ml}$.

The first test procedure was prepared well for blanks and samples, but in the well blank no samples were added and Horseradish Peroxidase (HRP) - Conjugate. Subsequently, $40 \mu$ dilution samples were added to each well and $10 \mu \mathrm{l}$ samples were added to the test plate.After that the incubation process is begin using adhesive 
strip for 30 minutes at $37 \mathrm{oC}$. At the time, dilution wash solution used 1: 20 ratio and wash solution diluted 30 times by distilled water. The result OD wash solution are used during the washing process. At the time of washing, the adhesive strip is opened, the solution in the well is removed, then add washing buffer at every well for 30 seconds, after which it is dried. This washing process is done for 5 times. Added HRP-Conjugate reagent $50 \mu \mathrm{l}$ in each well except well blank. Then incubated after lid with adhesive strip for 30 minutes at $37 \mathrm{oC}$.After 30 minutes, it has been washed for 30 seconds for 5 repetitions. After the washing process continued with staining by adding Chromogen Solution A and Chromogen Solution B $50 \mu \mathrm{l}$ at each well for $15 \mathrm{~min}$ at $37^{\circ} \mathrm{C}$. After 15 minutes, stop reaction is done by adding stop solution $50 \mu \mathrm{l}$ in every well, in this reaction process will change the color from blue to yellow and we have to wait for 15 minutes. After 15 minutes an absorbance reading was performed using a $450 \mathrm{~nm}$ ELISA reader with a blank well of zero value.

The growth hormone level of the sample was determined using the $\mathrm{Y}=\mathrm{e}^{\mathrm{a}+\mathrm{bx}}[11]$ equation, where $\mathrm{Y}$ was the growth hormone level in the cattle serum, a is the ratio between growth hormone level concentration and O.D, $\mathrm{x}$ is O.D, and $\mathrm{b}$ is the coefficient.

\section{Data analysis}

Research data has been analyzing with analysis of variance, and if the result is real difference then in will continue with the LSD test (Least significantdifferences). The analytical procedures will follow the instructions of Sampurna and Nindhia [12], using the SPSS (Statistical product and service solutions) program.

\section{III.RESULTS AND ANALYSIS}

The results of the test against the serum samples from the four treatments are optical density (O.D) values. The growth hormone levelwas determined by the equation $\mathrm{Y}=\mathrm{e}^{5,261+1,199 \mathrm{x}}$ with $\mathrm{X}$ as the value of O.D. The mean analysis of growth hormone level of male and female cattle after giving ethinyl estradiol and progesterone hormone combined with mineral is presented in Table 1.

TABLE 1. AVERAGE LEVELS OF GROWTH HORMONE BALI CATTLE

\begin{tabular}{ccc}
\hline Variables & $\begin{array}{c}\text { Average Levels of Growth } \\
\text { Hormone }(\mathrm{pg} / \mathrm{ml})\end{array}$ & Notation \\
\hline Female & $236.25 \pm 13.79$ & $\mathrm{a}$ \\
Male & $268.28 \pm 73.13$ & $\mathrm{~b}$ \\
Adult & $239.59 \pm 14.05$ & $\mathrm{a}$ \\
Young & $264.94 \pm 74.42$ & $\mathrm{~b}$ \\
No Minerals & $237.56 \pm 11.05$ & $\mathrm{a}$ \\
Minerals & $266.97 \pm 74.15$ & $\mathrm{~b}$ \\
No Hormone & $241.22 \pm 14.80$ & $\mathrm{a}$ \\
Hormone & $263.31 \pm 74.80$ & $\mathrm{~b}$ \\
\hline
\end{tabular}

Information: The mean growth hormone level is the mean \pm SEM value. The values with the letters (a) show no significant difference $(\mathrm{P}>0.05)$, while the values with the letters $(\mathrm{b})$ show significantly different $(\mathrm{P}$ $<0.05)$.

The administration of ethinyl estradiol and progesterone hormones combined with minerals in cattle significantly $(\mathrm{P}<0.05)$ was higher than in female cattle. 
The administration of ethinyl estradiol and progesterone hormones combined with minerals in young cattle was significantly higher $(\mathrm{P}<0.05)$ than in adult cattle.

Provision of minerals in bali cattle significantly $(\mathrm{P}<0.05)$ higher than without mineral administration.

The provision of ethinyl estradiol and progesterone hormones in bali cattle was significantly $(\mathrm{P}<0.05)$ higher than without the administration of ethinyl estradiol and progesterone hormones.

The mean analysis of growth hormone levels of male and female calves, young and adult age, ethinyl estradiol and progesterone and mineral hormones is presented in Table 2 .

TABLE 2. AVERAGE LEVELS OF GROWTH HORMONE BALI CATTLE MALE AND FEMALE, YOUNG AND MATURE, ETHINYL ESTRADIOL AND PROGESTERONE, AND MINERALS

\begin{tabular}{|c|c|c|c|c|c|}
\hline Sex & Age & Minerals & $\begin{array}{l}\text { Ethinyl Estradiol and } \\
\text { Progesterone }\end{array}$ & $\begin{array}{l}\text { Average Levels of } \\
\text { Growth Hormone } \\
(\mathrm{pg} / \mathrm{ml})\end{array}$ & Notation \\
\hline \multirow{8}{*}{ Male } & \multirow[t]{4}{*}{ Young } & \multirow[t]{2}{*}{ M0 } & $\mathrm{HO}$ & $252.75 \pm 11.33$ & $\mathrm{a}$ \\
\hline & & & $\mathrm{H} 1$ & $243.25 \pm 2.63$ & $\mathrm{a}$ \\
\hline & & \multirow[t]{2}{*}{ M1 } & $\mathrm{HO}$ & $262.75 \pm 5.66$ & $\mathrm{a}$ \\
\hline & & & $\mathrm{H} 1$ & $417.75 \pm 139.33$ & $\mathrm{~b}$ \\
\hline & \multirow[t]{4}{*}{ Adult } & \multirow[t]{2}{*}{ M0 } & $\mathrm{HO}$ & $242.50 \pm 13.63$ & $\mathrm{a}$ \\
\hline & & & $\mathrm{H} 1$ & $231.50 \pm 4.50$ & $\mathrm{a}$ \\
\hline & & \multirow[t]{2}{*}{ M1 } & $\mathrm{HO}$ & $243.75 \pm 14.22$ & $\mathrm{a}$ \\
\hline & & & $\mathrm{H} 1$ & $252.00 \pm 21.19$ & $\mathrm{a}$ \\
\hline \multirow{8}{*}{ Female } & \multirow[t]{4}{*}{ Young } & \multirow[t]{2}{*}{ M0 } & $\mathrm{HO}$ & $232.50 \pm 10.34$ & $\mathrm{a}$ \\
\hline & & & H1 & $235.25 \pm 2.75$ & $\mathrm{a}$ \\
\hline & & \multirow[t]{2}{*}{ M1 } & $\mathrm{HO}$ & $228.75 \pm 4.34$ & $\mathrm{a}$ \\
\hline & & & $\mathrm{H} 1$ & $246.50 \pm 27.97$ & $\mathrm{a}$ \\
\hline & \multirow[t]{4}{*}{ Adult } & \multirow[t]{2}{*}{ M0 } & $\mathrm{HO}$ & $231.00 \pm 14.90$ & $\mathrm{a}$ \\
\hline & & & $\mathrm{H} 1$ & $231.75 \pm 2.63$ & $\mathrm{a}$ \\
\hline & & \multirow[t]{2}{*}{ M1 } & $\mathrm{HO}$ & $235.75 \pm 8.58$ & $\mathrm{a}$ \\
\hline & & & $\mathrm{H} 1$ & $248.50 \pm 15.71$ & $\mathrm{a}$ \\
\hline
\end{tabular}

Information: The mean growth hormone rate is the mean \pm SEM. The values with the same letters show no significant difference $(\mathrm{P}>0.05)$, whereas values with different letters show significantly different $(\mathrm{P}$ $<0.05)$. M0 = No Minerals. M1 = Mineral. H0 = No Hormones. H1 = Hormones.

The provision of ethinyl estradiol and progesterone and minerals in young male bali cattle was significantly higher $(\mathrm{P}<0.05)$ than adult bali cattle, young female cattle and adult females. The average rate of bovine growth hormone in four treatments is presented in Figure 1. 


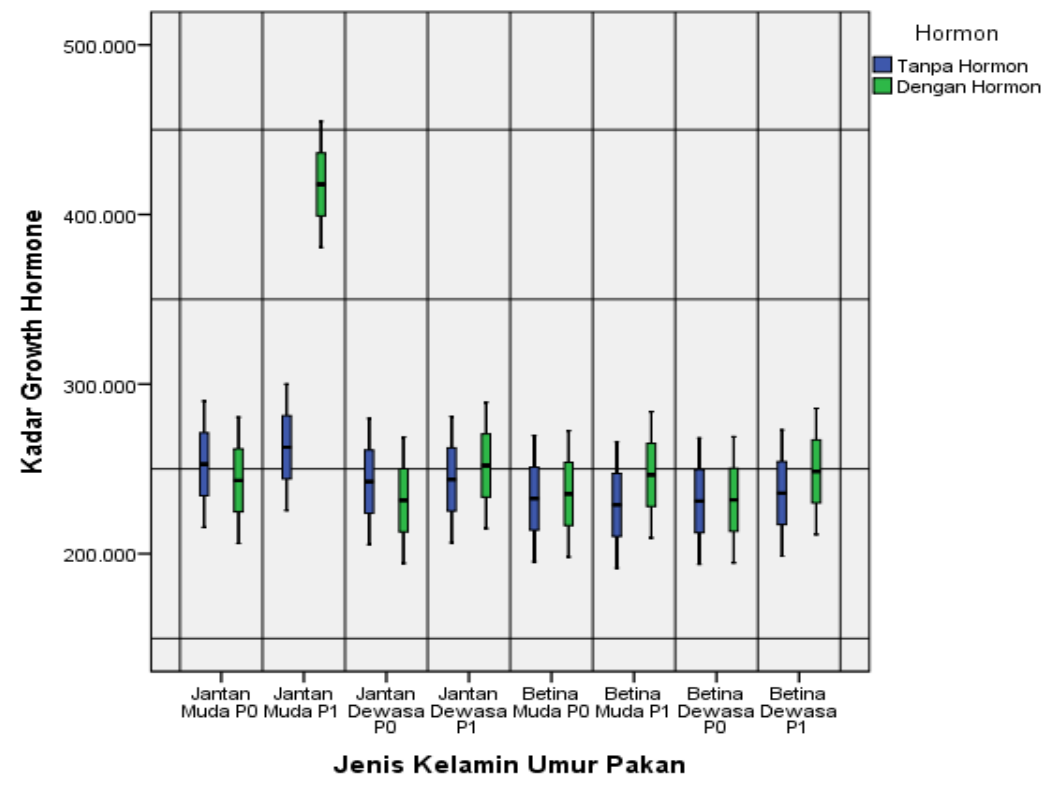

Figure 1. Mean of Bali Cattle Growth Hormone Level in Four Treatments

Figure 1. shows that boxpotes did not intersect were significantly different $(\mathrm{P}$ $<0.05)$ in which young cattle post-hormone ethinyl estradiol and progesterone combined with minerals produced the highest growth hormone level $(417.75 \pm 139.33 \mathrm{pg} / \mathrm{ml})$. Whereas the intersecting boxplot was not significantly different $(\mathrm{P}>0.05)$ in which adult cattle, young and adult cattle without and post-hormonal administration of ethinyl estradiol and progesterone combined with minerals produced an insignificant growth hormone level. The growth hormonelevel of the four treatments varied (Table 2.), the mean \pm highest cattle SEM (417.75 \pm $139.33 \mathrm{pg} / \mathrm{ml}$ ) in young cattle administered ethinyl estradiol and progesterone hormones combined with administration minerals, while the lowest $(231,000 \pm 14.90 \mathrm{pg} / \mathrm{ml})$ in adult female cattle without the administration of ethinyl estradiol, progesterone and mineral hormones. This situation is due to the growth of livestock that is directly affected by their natural habitat (external) and genetic (internal). External factors that affect growth are the places of maintenance associated with feed conditions, while the internal factors that affect growth are growth hormones [13].

Table 1 shows that the administration of ethinyl estradiol and progesterone hormones combined with minerals in malescattle significantly $(\mathrm{P}<0.05)$ was higher $(268.28 \pm$ $73.13 \mathrm{pg} / \mathrm{ml})$ than in female cattle $(236.25 \pm$ 13.79). Similar results have also been performed by [14], namely the average growth hormone level in male angus cattle $(20.8 \pm 2.2 \mathrm{ng} / \mathrm{ml})$, females $(14.9 \pm 1.8 \mathrm{ng} /$ $\mathrm{ml})$, cattle hereford male $(15.7 \pm 3.4 \mathrm{ng} /$ $\mathrm{ml})$, female $(11.8 \pm 2.7 \mathrm{ng} / \mathrm{ml})$, male shorthorn cattle $(15.9 \pm 5.8 \mathrm{ng} / \mathrm{ml})$, females (12.1 $\pm 3.8 \mathrm{ng} / \mathrm{ml})$, male crossbred cattle $(17.4 \pm 2.3 \mathrm{ng} / \mathrm{ml})$, females $(12.7 \pm 2.7 \mathrm{ng} /$ $\mathrm{ml})$.This is due to gender affecting in growth hormone secretion [15]. The same idea is also expressed by [16] that growth hormone is influenced by sex thus causing differences in weight gain in cattle.

The high growth hormone level of cattle is due to androgen hormones. Male animals grow faster than females at the same age as having testosterone one of the androgen steroids, which is the growth hormone produced by interstitial cells and adrenal 
glands.Androgen hormones in male animals can stimulate growth, and also rapid growth at puberty is partly due to the anabolic effects of proteins from androgens so that male animals can be larger than females [17].One of the androgen steroids that affects growth hormone is testosterone that has the ability of protein anabolism to stimulate growth hormone production from hypophysis [18].

Growth hormone in female cattle is also involved in the process of sexual differentiation and puberty and has a role in the steroidogenesis of gonads, gametogenesis, and ovulation [19]. Female sex hormones, such as estrogen produced by ovaries generally have little or no effect on protein and skeletal synthesis, but are effective in increasing body fat formation. Therefore, females stop growing faster than males [20].

This process is directly affectsgrowth hormone activity in the pituitary gland [21]. Growth hormone also works on gonads, placentas, and mammary glands of female animals [22]. This is causing the growth of males faster than females especially after secondary sex traits arise where male animal growth is higher than female animals of the same age [23].

The administration of ethinyl estradiol and progesterone hormones combined with minerals in young cattle $(\mathrm{P}<0.05)$ was higher $(264.94 \pm 74.42 \mathrm{pg} / \mathrm{ml})$ than in adult cattle $(239.59 \pm 14.05 \mathrm{pg} / \mathrm{ml})$ (Table 1$)$. The growth hormone level of bali cattle began to increase significantly from a young age (618 months), but in adulthood (18 months) there was no increase in growth hormone. This is because at a young age (6-18 months) the cattleneeds nutrient intake for the growing period, the protein used to build the body's tissue that is forming muscles,nails, blood cells and bones so that growth hormone plays an important role in body composition, muscle metabolism, bone, in the function of organs to maintain homeostasis, so there is also a change in weight gain. At the time of growing the growth hormone levels are in optimal condition so as to achieve excellent biological performance and various organs of the body can work well [24].

That giving minerals for bali cattle was significantly higher $(\mathrm{P}<0.05)$ higher $(266.97$ $\pm 74.15 \mathrm{pg} / \mathrm{ml}$ ) compared with no mineral $(237.56 \pm 11.05 \mathrm{pg} / \mathrm{ml})$ (Table 1). Geographically Mupu Amerta farm is located in Bangli Regency, Bali Province, which is a highland area. Agroecosystem conditions (rainfall, land characteristics, temperature and humidity) from the height of the maintenance site indirectly affect the availability of forage fodder in terms of both quality and quantity [25].

Feed is very influential on growth hormone levels. This growth hormone is produced by somatrotop (part of the acidophilic cells) present in the pituitary gland. Indirectly, growth hormone works through IGF-1 produced by various tissues in response to growth hormone [26]. This hormone works through the intermediation of a peptide called somatomedin. Somatomedin is the main production in the liver is also affected by age and feed. Somatomedin is what will bind to receptors in the body's cells to stimulate growth through protein cystesis, carbohydrate metabolism, fat metabolism and mineral metabolism. High levels of calcium, magnesium and phosphate will stimulate long growth of hard bone and cartilage growth especially at young age. Minerals and proteins will increase IGF-1 levels in the body and in turn, deficiency of minerals and proteins can lower IGF-1 levels, resulting in a decrease in growth hormone secretion that ends in the decline in growth hormone level [27].

Fodder is very influential on the growth hormone level (growth hormone). Indirectly, 
growth hormone works through IGF-1 produced by various tissues in response to growth hormone [28]. One important factor in regulating IGF-1 is feed. Minerals and proteins will increase IGF-1 levels in the body and in turn, deficiency of minerals and proteins can lower IGF-1 levels, resulting in a decrease in growth hormone secretion that ends in the decline in growth hormone levelBesides IGF-1, another factor that affects the secretion of growth hormone is ghrelin. Ghrelin is one of the growth hormone Releasing Hormone (GHRH) released from the stomach. In secreting growth hormone, ghrelin is first regulated by fodder so that ghrelin is able to induce the release of growth hormone in the pituitary gland. The state of fodder deficiency will affect the release of growth hormone [29].

The provision of ethinyl estradiol and progesterone hormones in bali cattle was significantly higher $(\mathrm{P}<0.05)$ higher $(263.31$ $\pm 74.80 \mathrm{pg} / \mathrm{ml}$ ) than without ethinyl estradiol and progesterone hormones (241.22 \pm 14.80pg / ml) (Table 1). Hormones that play an important role in growth, namely somatotropin, thyroxine, androgens, a combination of estrogen and progesterone, and glucorticoid [30][31].In the case of growth hormone more than one organ becomes the target because growth hormone affects the tissues in the body. The ethinyl estradiol and progesterone hormones can enhance the growth hormone profile by stimulating the body's cells to accelerate growth so that the growth of the male vein is likely to be greater than the females. This condition that causes overall body size is affected by gender [32].

The growth hormone produced by the pituitary gland first flows through the blood vessels to the liver. In the liver, growth hormone is converted to IGF-1 (Insulin like Growth Factor-1). Then through the blood circulation IGF-1 is flow throughout the organs in the body. IGF-1 is responsible for maintain all the organs in the body [33]. Other factors that are known also affect the secretion of growth hormone are gender, age, fodder, and other hormones.

\section{CONCLUSION}

Based on the results of research that has been done, can be concluded as follows:

1. Age and sex affect the growth hormone levels of bali cattle in line with the provision of hormones ethinyl estradiol and progesterone combined with the provision of minerals.

2. Giving hormone ethinyl estradiol and progesterone combined with the provision of minerals significantly $(\mathrm{P}$ $<0.05)$ can increase the growth hormone profile of young bali cattle.

\section{SUGGESTION}

Giving hormone ethinyl estradiol and progesterone in bali cattle should be combined with minerals so as to increase the levels of growth hormone (growth hormone), and further research is needed to determine the residual content in blood and meat .

\section{ACKNOWLEDGMENT}

The authors would like to thank the Rector of CQ Bali Cattle Study Center of Udayana University for the support of the cost for this research, as well as to those who have assisted in the research process at the Biotechnology Laboratory of Veterinary Center Denpasar.

\section{REFERENCES}

[1] Oka IGL. 2010. Conservation and Genetic Improvement of Bali Cattle. Proc. Conservation and Improvement of World Indigenous Cattle. 110-117. 
[2] Gardner, D.G., Shoback, D. 2007. Greenspan's Basic and Clinical Endocrinology. Eighth Edition. San Fransisco: The Mc Graw-Hill Company.

[3] Thissen, J.P., Ketelslegers, J.M., Underwood, L.E. 1994. Nutritional Regulation of the Insulin-Like Growth Factors. Endocr. Rev, 15: 80-101.

[4] Robson, H., Siebler, T., Shalet, S.M., Williams, G.R. 2002. Interactions Between GH, IGF-I, Glucocorticoids, and Thyroid Hormones During Skeletal Growth. Pediatric Research, 52:137-147.

[5] Leung KC, Johannsson G, Leong GM, Ho KK. 2004. Estrogen regulation of growth hormone action. Endocr. Rev. 25, 693-72110.1210/er.20030035 .

[6] Lawrie, R, A. 2003.IlmuDaging(Meat Science). (Parakkasi, A., Pentj). Edisi ke-5. Jakarta: UI Press.

[7] Zhong, S., Wei-Ping, Y., Feng, E., Shu-Hong, L., Jie-Yu, L., Leong, J., Ma, C., Lin, Y.C. 2011. Serum Derivate from Zeranol-Implanted ACI Rats Promotes The Growth of Human Breast Cancer In Vitro. Anticancer Research,31(3): 481-486.

[8] Khadijah, S. 2012. Analisis Residu Zeranol Dalam Daging Sapi Yang Diimpor Dari Australia dan Selandia Baru Melalui Pelabuhan Tanjung Priok (tesis). Bogor: Institut Pertanian Bogor.

[9] Milfa S, Suwiti NK, Tenaya IWM. 2015. Profil Hormon Pertumbuhan Sapi Bali Betina Pada Tiga Tipe Lahan Pemeliharaan Di Provinsi Bali. Buletin Veteriner Udayana, Volume 7 No. 1: 1-8 p-ISSN: 2085-2495.

[10] Glory Science. 2017. Bovine Growth Hormone (GH) ELISA Kit. Catalog \#: D8569.
[11] Sampurna IP. 2012. Analisis Regresi Non-Linier Terapan Dengan SPSS. Pelawa Sari. Denpasar.

[12] Sampurna IP, Nindhia TS. 2008. Analisis Data dengan SPSS dalam Rancangan Percobaan. Udayana University Press. Denpasar.

[13] Herd, D.B., Sprott, L.R. 1986. Body Condition, Nutrition, and Reproduction of Beef Cows. Texas Agric. Ext. Ser. Bull, No. B-1526.

[14] Irvin, R., Trenkle, A. 1971. Influences of Age, Breed and Sex on Plasma Hormones in Cattle. J ANIM SCI, 32:292-295.

[15] Shimon, I., Taylor, J.E., Dong, J.Z. 1997. Somatostatin Receptor Subtype Specificity in Human Fetal Pituitary Cultures. Differential Role of SSTR2 and SSTR5 for 55. Growth Hormone, Thyroid-Stimulating Hormone, and Prolactin Regulation. J. Clin. Invest, 99: 789-798.

[16] Turner, C.D., Bagnara, J.T. 1976. W.B. A Course Manual in Nutrion and GrowthAustralian Vice-ChoncellorsCommittee, Melbourne. General Endocrinology. Sixth Editon. p. 28: $561-597$.

[17] Kay M. and R.Hausseman. 1997. The Influence of Sex on Meat Production InMeat. Edited by Cook DJ, Lawrrie RA. London. Butterworth.

[18] Vestergaard, M., Purup, S., Henckel, P., Tonner, E., Flint, D.J., Jensen, L.R., Sejrsen,K. 1995. Effects of $G H$ and Ovariectomy on Performance, Serum Hormones, IGH Binding Proteins, and Muscle Fibre Properties of Prepubertal FriesianHeifers. J. Anim. Sci. 73: 3574-3584.

[19] Hull, K.L., Harvey, S. 2001. Growth Hormone: Roles in Female Reproduction. Department of Physiology, University of Alberta. Edmonton, Canada. 
[20] Nasrul, L. 2012. Pertumbuhan dan Perkembangan Otot dan Jaringan Karkas. Prinsip dan Konsep dari Pertumbuhan dan Perkembangan.

[21] Sharara, F.I., Giudice, L.C. 1997. Role of Growth Hormone in Ovarian Physiology and Onset of Puberty. Journal of the Society for Gynecologic Investigation, 4:2-7.

[22] Lawrence, T.L.J., Fowler, V.R. 2002. Growth of Farm Animals. Walling Ford: CABI International. New York. USA.

[23] Irvin, R., Trenkle, A. 1971. Influences of Age, Breed and Sex on Plasma Hormones in Cattle. $J$ ANIM SCI, 32:292-295.

[24] Misitahari M. I. 2011. Pemberian Growth Hormone Menurunkan Kadar Tumor Necrosis Factor-A (Tnf-A) pada Tikus Jantan yang Dislipidemia. Disertasi tidak diterbitkan. Denpasar: Universitas Udayana Denpasar.

[25] Gregory, K.E. 1961. Improvement of Beef Cattle Through Breeding Methode. Regional Publication 120. USDA.

[26] Gardner, D.G., Shoback, D. 2007. Greenspan's Basic and Clinical Endocrinology. Eighth Edition. San Fransisco: The Mc Graw-Hill Company.
February 2019 Vol. 2 No.1: 1 - 9

[27] Thissen, J.P., Ketelslegers, J.M., Underwood, L.E. 1994. Nutritional Regulation of the Insulin-Like Growth Factors. Endocr. Rev, 15: 80-101.

[28] Pangkahila W. 2007. Anti-Aging Medicine: Memperlambat Penuaan Meningkatkan Kualitas Hidup. Cetakan ke-1. Jakarta: Penerbit Buku Kompas.

[29] Kojima, M., Hosoda, H., Matsuo, H., Kangawa, K. 2001. Ghrelin: Discovery of the Natural Endogenous Ligand for the Growth Hormone Secretagogue Receptor.Trends in Endocrinology and Metabolism, 12:118-122.

[30] Robson, H., Siebler, T., Shalet, S.M., Williams, G.R. 2002. Interactions Between GH, IGF-I, Glucocorticoids, and Thyroid Hormones During Skeletal Growth. Pediatric Research, 52:137-147.

[31] Leung KC, Johannsson G, Leong GM, Ho KK. 2004. Estrogen regulation of growth hormone action. Endocr. Rev. 25, 693-72110.1210/er.20030035.

[32] Kay M. and R.Hausseman. 1997. The Influence of Sex on Meat Production In Meat. Edited by Cook DJ, Lawrrie RA. London. Butterworth.

[33] Thissen, J.P., Ketelslegers, J.M., Underwood, L.E. 1994. Nutritional Regulation of the Insulin-Like Growth Factors. Endocr. Rev, 15: 80-101. 